\title{
Isoleucine Regulates the Synthesis of Pancreatic Enzymes via the Activation of mRNA Expression and Phosphorylation in the Mammalian Target of Rapamycin Signalling Pathways in Pancreatic Tissues
}

\author{
Yangchun Cao, ${ }^{1}$ Kai Liu, ${ }^{1}$ Shimin Liu, ${ }^{2}$ Long Guo, ${ }^{1}$ Chuanjiang Cai, ${ }^{1}$ and Junhu Yao $\mathbb{D}^{1}$ \\ ${ }^{1}$ College of Animal Science and Technology, Northwest A\&F University, Yangling 712100, China \\ ${ }^{2}$ UWA School of Agriculture and Environment, the University of Western Australia, Crawley, WA 6009, Australia
}

Correspondence should be addressed to Junhu Yao; yaojunhu2004@sohu.com

Received 27 March 2019; Accepted 23 May 2019; Published 18 June 2019

Academic Editor: Bo Zuo

Copyright (C) 2019 Yangchun Cao et al. This is an open access article distributed under the Creative Commons Attribution License, which permits unrestricted use, distribution, and reproduction in any medium, provided the original work is properly cited.

\begin{abstract}
This study aimed to investigate the effects of isoleucine (Ile) on the synthesis and secretion of digestive enzymes and cellular signalling in the pancreatic tissue of dairy goats. The pancreatic tissues were incubated in buffer containing $0,0.40,0.80$, and $1.60 \mathrm{mM}$ Ile. High levels of Ile significantly increased the buffer release and total concentration of a-amylase in the tissues $(\mathrm{P}<$ 0.001). The total trypsin and chymotrypsin concentrations in each of the Ile groups were significantly higher than those in the control group $(\mathrm{P}<0.05)$; however, lipase was not affected. High levels of Ile significantly increased a-amylase mRNA expression $(\mathrm{P}<0.001)$ but had no effect on the mRNA expression of trypsin, chymotrypsin, or lipase. Ile did not affect S6K1 phosphorylation levels. High levels of Ile significantly increased the expression of the $\gamma$ isoform of 4EBP1 $(\mathrm{P}<0.001)$, which indicated that the phosphorylation of 4EBP1 was significantly increased. The phosphorylation level of eEF2 gradually decreased with the addition of Ile $(\mathrm{P}<0.001)$. These results suggested that high doses of Ile can regulate the excretion of enzymes, especially a-amylase, in the pancreatic tissues of dairy goats by modulating mTOR signalling, and this regulation is independent of the mTOR-S6K1 pathway.
\end{abstract}

\section{Introduction}

The specificity of ruminal digestion is different from that of monogastric animals. Studies on the digestive functions of ruminants have thus mostly concentrated on the rumen, whereas relatively few studies exist on the metabolism of nutrients that bypass the rumen. The digestion of rumen bypass nutrients depends on the digestive enzymes secreted by the intestine and other organs, including amylase, oligosaccharides, polysaccharide-hydrolysing enzymes, trypsin, chymotrypsin, and lipase, among others, of which pancreatic exocrine digestive enzymes (a-amylase, trypsin, and lipase) predominate. Recent studies have shown that inadequate secretion of pancreatic a-amylase might limit intestinal starch utilization in ruminants [1,2]. The energy utilization efficiency of starch degraded in the small intestine is $42 \%$ higher compared with its fermentation products in the rumen, which can help to avoid rumen acidosis [3]. Therefore, improving the exocrine function of the pancreas is conducive to improving the digestion and utilization of rumen bypass nutrients. Proteins and amino acids play important roles in animal energy balance, protein synthesis, function, and substance transformation, and functional amino acids (leucine, isoleucine, phenylalanine, etc.) can be used as signalling molecules to control metabolic function in animals $[4,5]$.

An increasing number of scholars have begun to focus on the study of branched-chain amino acids. Branchedchain amino acids are a group of neutral, aliphatic amino acids with a branched carbon chain structure and include leucine, isoleucine (Ile) and valine [6]. Leucine is a ketogenic amino acid, Ile is both glucogenic and ketogenic, and proline is a glucogenic amino acid [6]. Animals cannot synthesize branched-chain amino acids and the intake of these amino acids occurs only through food. Branched-chain 
amino acids mainly have physiological functions including repairing muscles, promoting gluconeogenesis, oxidizing and supplying energy for the body, enhancing immunity, and promoting hormone synthesis and secretion $[7,8]$. Branchedchain amino acids are functional amino acids. Our research group has devoted many years to the study of functional amino acids and pancreatic exocrine function in ruminants, especially leucine [9-11]; however, Ile, a similar branchedchain and functional amino acid, has been rarely investigated. Like leucine, Ile not only is a substrate for protein synthesis but also plays an important role in intracellular protein synthesis signalling pathways [7]. A study in monogastric animals showed that Ile increased milk protein and milk fat production rates in sows [8]. Previous studies in fish showed that Ile increased the growth rate, feed intake, protein synthesis, and protein deposition in juvenile Jian carps and that the activities of trypsin, chymotrypsin, lipase, and amylase were improved [12]. Ile also has an important regulatory role in protein synthesis. Few studies on Ile in ruminants exist and even fewer studies regarding the effects of Ile on pancreatic functions have been done.

Mammalian target of rapamycin (mTOR) is a highly conserved protein factor that can regulate the growth and metabolism of animals through a mechanism involving the regulation of protein synthesis that is relatively clear [13, 14]. mTOR plays a very important role in the initial stage of translation. Amino acids can regulate protein synthesis by affecting the phosphorylation levels of upstream and downstream target protein molecules in the mTOR pathway [15]. The best-characterized downstream effectors of mTOR include two signaling pathways that act in parallel to control mRNA translation: the 70-kDa ribosomal protein S6 kinase 1 (S6K1) pathway and the eukaryotic translation initiation factor $4 \mathrm{E}$ binding protein 1 (4EBP1) pathway [16]. mTOR activated by amino acids, in turn, catalyses the phosphorylation of ribosomal protein S6K1 and 4EBP1 [17]. Another potentially important signaling protein in the control of translation is eukaryotic elongation factor 2 (eEF2), which is indirectly regulated by mTOR through $\mathrm{S} 6 \mathrm{~K} 1$ [18]. In mammalian epithelial cell culture assays [19, 20], the level of mTOR phosphorylation was approximately 100\% higher in the $3.5 \mathrm{mM}$ essential amino acid group compared to the nonessential amino acid group $(\mathrm{P}<0.001)$. With the removal of Ile alone, the level of mTOR phosphorylation was decreased by $47 \%(\mathrm{P}<0.05)$. Under energy or amino acid depletion conditions, intracellular mTORC1 signalling is strongly inhibited, while the resupplementation of amino acids to starved cells can significantly stimulate mTORC1 activity [8]. However, the mechanisms by which amino acids act as mTORC1 signalling factors remain unclear.

The aim of this study was to investigate the molecular mechanisms and signalling pathways associated with Ile and the regulation of pancreatic exocrine function.

\section{Materials and Methods}

All procedures used in this study complied with an animal care protocol that was approved by the Northwest A\&F University Animal Care and Use Committee.
TABLE 1: Ingredients and chemical composition of the experimental diet.

\begin{tabular}{lc}
\hline Item & $\%(\mathrm{DM})$ \\
\hline Ingredient & \\
Alfalfa hay & 17.50 \\
Corn silage & 27.50 \\
Corn & 40.00 \\
Soybean meal & 13.00 \\
Calcium phosphate & 0.25 \\
Limestone & 0.75 \\
NaCl & 0.50 \\
Vitamin-mineral premix ${ }^{1}$ & 0.50 \\
Nutrient composition & \\
DM & 50.58 \\
ADF & 18.88 \\
NDF & 34.38 \\
CP & 16.40 \\
Starch & 27.66 \\
\hline
\end{tabular}

${ }^{1}$ Vitamin-mineral premix (per kg): $600 \mathrm{mg}$ of Mn, $950 \mathrm{mg}$ of $\mathrm{Zn}, 430 \mathrm{mg}$ of $\mathrm{Fe}, 650 \mathrm{mg}$ of $\mathrm{Cu}, 30 \mathrm{mg}$ of Se, $45 \mathrm{mg}$ of I, $20 \mathrm{mg}$ of Co, $450 \mathrm{mg}$ of nicotinic acid, $800 \mathrm{mg}$ of vitamin E, 45,000 IU of vitamin D, and 120,000 IU of vitamin A.

2.1. Pancreatic Tissue Preparation. Pancreatic tissue was obtained from three different, 1-year-old, healthy Guanzhong dairy goats. A total mixed ration (Table 1) composed of alfalfa hay $(17.5 \%$ of dry matter (DM)), corn silage $(27.5 \%$ of $\mathrm{DM})$, and concentrate $(55.0 \%$ of DM) was prepared for the goats. Goats were fed twice daily at 0700 and $1900 \mathrm{~h}$ on an ad libitum basis (allowing for 5-10\% orts) with free access to fresh water. Three goats were slaughtered over 3 days, one goat per day, to provide fresh pancreatic tissues for culturing.

Approximately $10 \mathrm{~g}$ of pancreas tissue was quickly excised after animal slaughtering, placed in cold normal saline $(0.9 \%$ $\mathrm{NaCl}$ ), and immediately sent to the laboratory. The tissue was transferred to KRB buffer (25 mM HEPES, pH 7.4, $118 \mathrm{mM} \mathrm{NaCl}, 4.7 \mathrm{mM} \mathrm{KCl}, 1.2 \mathrm{mM} \mathrm{MgSO}_{4}, 2.5 \mathrm{mM} \mathrm{CaCl}_{2}$, and $1.2 \mathrm{mM} \mathrm{KH}_{2} \mathrm{PO}_{4}$ ) [21] and cut into pieces $2 \times 2 \mathrm{~mm}$ in size. After moisture removal with absorbent papers, tissue pieces were weighed and then transferred to a culture bottle containing $3 \mathrm{~mL}$ of $\mathrm{KRB}$ solution. The culture bottle was placed in a cell incubator $\left(95 \% \mathrm{O}_{2} \quad 15 \% \mathrm{CO}_{2}\right)$ with the bottle cap left open for incubation. After incubation, the culture bottle was placed on ice and the buffer was collected and stored frozen. The buffer was used to determine the amount of enzymes released from the pancreatic tissue. The pancreatic tissue was frozen and then used to determine the enzyme activities (a-amylase, trypsin, and lipase), as well as the mRNA abundance and activity and the degree of phosphorylation of the mTOR signalling pathway factors (4EBP1, S6K1, and eEF2).

2.2. Treatments and Experimental Design. The Ile solutions containing Ile at $0 \mathrm{mg} / \mathrm{mL}, 2.62 \mathrm{mg} / \mathrm{mL}, 5.24 \mathrm{mg} / \mathrm{mL}$, and $10.48 \mathrm{mg} / \mathrm{mL}$ were prepared in KRB buffer and were added to cell culture medium to achieve final Ile concentrations of $0 \mathrm{mM}, 0.40 \mathrm{mM}, 0.80 \mathrm{mM}$, and $1.60 \mathrm{mM}$, respectively. 
TABLE 2: Real-time PCR primers.

\begin{tabular}{|c|c|c|c|c|}
\hline Gene name & Reference sequence & Primer sequence $\left(5^{\prime}-3^{\prime}\right)$ & $\begin{array}{l}\text { Product size } \\
\text { (bp) }\end{array}$ & $\begin{array}{c}\text { Annealing } \\
\text { temperature }\left({ }^{\circ} \mathrm{C}\right)\end{array}$ \\
\hline \multirow{2}{*}{ Amylase } & \multirow{2}{*}{ NM_001035016 } & F: GAAATGGCCGTGTGACAGAATTTA & \multirow{2}{*}{142} & \multirow{2}{*}{64.3} \\
\hline & & R: ACAAAGACAAGTGCCCTGTCAGAA & & \\
\hline \multirow{2}{*}{ Trypsin } & \multirow{2}{*}{ NM_001113727 } & F: TGTCTGCGGCTCACTGCTAC & \multirow{2}{*}{119} & \multirow{2}{*}{62.7} \\
\hline & & R: GCTGGGATGGACGATACTCTTG & & \\
\hline \multirow{2}{*}{ Chymotrypsin } & \multirow{2}{*}{ NM_001098965.1 } & F: ATGTTGGGCATCACGGTCTT & \multirow{2}{*}{172} & \multirow{2}{*}{60.0} \\
\hline & & R: TGTGCCTCCACGTGTTATCC & & \\
\hline \multirow{2}{*}{ Lipase } & \multirow{2}{*}{ NM_001205820 } & F: GTGGAAGCAAATGATGGACAAG & \multirow{2}{*}{81} & \multirow{2}{*}{61.8} \\
\hline & & R: TGGGTTGAGGGTGAGCAGA & & \\
\hline \multirow{2}{*}{$\beta$-Actin } & \multirow{2}{*}{ AF481159 } & F: ACCACTGGCATTGTCATGGACTCT & \multirow{2}{*}{152} & \multirow{2}{*}{60.0} \\
\hline & & R: TCCTTGATGTCACGGACGATTTCC & & \\
\hline
\end{tabular}

The incubation time was $180 \mathrm{~min}$ and three replicates were included for each treatment. After incubation for $180 \mathrm{~min}$, tissues were harvested by scraping in the presence of ice-cold lysis buffer containing $1 \%(\mathrm{v}: \mathrm{v})$ of protease and phosphatase inhibitors cocktail (Roche, China). The culture medium was also collected for further analysis of enzyme activities. In total, each Ile treatment included three replicates from three goats $(n=3)$.

\subsection{Sample Analysis}

2.3.1. Chemical Composition of Diet. Feed samples were collected, dried at $55^{\circ} \mathrm{C}$ for $72 \mathrm{~h}$, and then ground through a $1 \mathrm{~mm}$ screen. These samples were analysed using the procedures described by AOAC (1999) for dry matter (DM, ID 930.5) and crude protein (CP, N×6.25; ID 984.13) [22]. The neutral detergent fibre (NDF) and acid detergent fibre (ADF) contents were determined according to the method of Van Soest et al. [23] using sodium sulphite and a heat-stable $\alpha$-amylase (Ankom A200I fibre analyser, Ankom Technology, Macedon, NY). The starch content in the bag was determined using an enzymatic method ( $\alpha$-amylase and amyloglucosidase) with a commercial starch analysis kit (Megazyme, Megazyme International Ireland Ltd., Bray, Ireland).

2.3.2. In Vitro Enzyme Release. To measure the activity of the digestive enzymes in the tissue segments, the homogenate supernatant was collected after homogenizing. The activity of $\alpha$-amylase, trypsin, and lipase in the supernatant and culture medium were determined using commercial kits (Nanjing Jiancheng Bioengineering Institute, China). One unit of enzyme activity was defined as $1 \mu \mathrm{mol}$ of the product released per minute at $39^{\circ} \mathrm{C}$.

2.3.3. Quantification of Amylase, Trypsin, and Lipase $m R N A$ Levels. RNA extraction was performed according to the method described by Wathes et al. [24]. Frozen pancreatic tissue samples were homogenized with $1 \mathrm{~mL}$ of Trizol (Invitrogen, USA) and the supernatants were collected by centrifugation. RNA was precipitated by adding chloroform, followed by isopropanol. The RNA pellet was rinsed with $75 \%$ ethanol and dissolved in RNAse-free water. Total RNA was measured using $260 \mathrm{~nm}$ spectrometry.

Reverse transcription was performed using the RNA PCR Kit 3.0 (TAKaRa Biotechnology (Dalian) Co. Ltd., China). Solutions included $2 \mu \mathrm{L}$ of $\mathrm{MgCl}_{2}, 3.75 \mu \mathrm{L}$ of RNAse-free water, $1 \mu \mathrm{L}$ of $10 \times$ RT buffer, $0.25 \mu \mathrm{L}$ of RNAse inhibitor, $1 \mu \mathrm{L}$ of $\mathrm{dNTP} \operatorname{mix}, 0.5 \mu \mathrm{L}$ of random primers, $0.5 \mu \mathrm{L}$ of AMV reverse transcriptase, and $1 \mu \mathrm{L}$ of the RNA sample. The reaction conditions were as follows: $42^{\circ} \mathrm{C}$ for $30 \mathrm{~min}, 95^{\circ} \mathrm{C}$ for $5 \mathrm{~min}, 5^{\circ} \mathrm{C}$ for $5 \mathrm{~min}$, and storage at $-20^{\circ} \mathrm{C}$.

For quantitative real-time $\mathrm{PCR}, 25 \mu \mathrm{L}$ of the reaction system containing SYBR Green (TAKaRa Biotechnology (Dalian) Co. Ltd., China) was used. The reaction solution contained $12.5 \mu \mathrm{L}$ of $2 \times$ SYBR premix Ex Taq II, $2 \mu \mathrm{L}$ of sample cDNA, $8.5 \mu \mathrm{L}$ of $\mathrm{dH}_{2} \mathrm{O}, 1 \mu \mathrm{L}$ of $10 \mu \mathrm{mol} / \mathrm{L}$ forward primer, and $1 \mu \mathrm{L}$ of $10 \mu \mathrm{mol} / \mathrm{L}$ reverse primer. The reaction conditions were as follows: predenaturation at $95^{\circ} \mathrm{C}$ for $30 \mathrm{~s}$, $40 \mathrm{cycles}$ of denaturation at $95^{\circ} \mathrm{C}$ for $5 \mathrm{~s}$, annealing at $63^{\circ} \mathrm{C}$ for $30 \mathrm{~s}$ (different temperatures for different primers), and final extension at $72^{\circ} \mathrm{C}$ for $10 \mathrm{~min}$. Primers for a-amylase, trypsin, chymotrypsin, lipase, and $\beta$-actin are listed in Table 2 [4]. mRNA expression was determined using the $2{ }^{-}{ }^{\Delta \Delta} \mathrm{CT}$ method [25] with $\beta$-actin used as the housekeeping gene [26].

2.3.4. Protein Immunoblot Analysis. Western blot analysis was performed according to the methods described by Crozeir et al. [27]. The frozen tissue samples were ground to powders with a mortar (under a liquid nitrogen environment) and then homogenized using $2 \mathrm{~mL}$ of cold lysis buffer $(\mathrm{pH}=$ 7.4). The lysis buffer contained the following: $50 \mathrm{mM}$ Tris $\mathrm{HCl}$, $25 \mathrm{mM}$ sodium fluoride, $5 \mathrm{mM}$ ethylenediaminetetraacetic acid, $50 \mathrm{mM} \beta$-glycerophosphate, $10 \mathrm{mM}$ sodium pyrophosphate, $0.2 \mathrm{mM}$ sodium vanadate, $1 \mathrm{mM}$ benzylsulfonyl fluoride, $0.2 \%$ polyethylene glycol octyl phenyl ether $(\mathrm{v} / \mathrm{v}), 1 \mathrm{mM}$ dithiothreitol, $10 \mu \mathrm{g} / \mathrm{mL}$ aprotinin, $5 \% \beta$-mercaptoethanol $(\mathrm{v} / \mathrm{v})$, and $10 \mu \mathrm{g} / \mathrm{mL}$ leupeptin. Upon homogenization, the solution was immediately centrifuged $\left(20000 \times \mathrm{g}, 4^{\circ} \mathrm{C}\right.$, $15 \mathrm{~min}$ ) to collect the supernatant, which was then boiled for $15 \mathrm{~min}$ and centrifuged a second time $(10000 \times \mathrm{g}$, $\left.4^{\circ} \mathrm{C}, 30 \mathrm{~min}\right)$. The new supernatant was collected for use in immunoblot analyses to determine 4EBP1, S6K1, and 
TABLE 3: The effects of isoleucine on the activities of enzymes in vitro.

\begin{tabular}{|c|c|c|c|c|c|c|}
\hline \multirow{2}{*}{ Item } & \multicolumn{4}{|c|}{ Level of isoleucine $\left(\mathrm{mM}^{1}\right)$} & \multirow{2}{*}{$\mathrm{SEM}^{2}$} & \multirow{2}{*}{ P-value } \\
\hline & 0 & 0.40 & 0.80 & 1.60 & & \\
\hline \multicolumn{7}{|c|}{ Tissue concentration (U/g) } \\
\hline a-amylase & $814^{\mathrm{b}}$ & $923^{\mathrm{b}}$ & $4207^{\mathrm{a}}$ & $3631^{\mathrm{a}}$ & 244.7 & $<0.001$ \\
\hline Trypsin & 4.45 & 5.13 & 4.87 & 4.91 & 0.445 & 0.148 \\
\hline Chymotrypsin & 3.51 & 4.12 & 4.32 & 4.28 & 0.629 & 0.093 \\
\hline Lipase & 587 & 634 & 608 & 616 & 88.6 & 0.347 \\
\hline \multicolumn{7}{|l|}{ Release (U/g tissue) } \\
\hline a-amylase & $325^{\mathrm{b}}$ & $308^{\mathrm{b}}$ & $876^{\mathrm{a}}$ & $804^{\mathrm{a}}$ & 48.3 & $<0.001$ \\
\hline Trypsin & 1.92 & 2.14 & 2.06 & 2.26 & 0.318 & 0.271 \\
\hline Chymotrypsin & 1.22 & 1.56 & 1.48 & 1.49 & 0.475 & 0.248 \\
\hline Lipase & 189 & 195 & 213 & 204 & 49.7 & 0.418 \\
\hline \multicolumn{7}{|c|}{ Total activity (U/g tissue) } \\
\hline a-amylase & $1139^{\mathrm{b}}$ & $1231^{\mathrm{b}}$ & $5083^{\mathrm{a}}$ & $4435^{\mathrm{a}}$ & 138.1 & $<0.001$ \\
\hline Trypsin & $6.37^{\mathrm{b}}$ & $7.27^{\mathrm{a}}$ & $6.93^{\mathrm{a}}$ & $7.17^{\mathrm{a}}$ & 0.582 & 0.014 \\
\hline Chymotrypsin & $4.73^{\mathrm{b}}$ & $5.68^{\mathrm{a}}$ & $5.80^{\mathrm{a}}$ & $5.77^{\mathrm{a}}$ & 0.536 & 0.028 \\
\hline Lipase & 776 & 819 & 821 & 820 & 72.3 & 0.303 \\
\hline
\end{tabular}

${ }^{1}$ One-way ANOVA. Differences were considered significant at $\mathrm{P}<0.05$.

${ }^{2}$ Pooled standard error of the means, $\mathrm{n}=3$.

eEF2 expression. Prior to western blot analysis, the sample was boiled for $5 \mathrm{~min}$ and then cooled on ice. The western blot procedure was as follows: first, protein separation was conducted based on the protein molecular weight using sodium dodecyl sulphate-polyacrylamide gel electrophoresis (SDS-PAGE) with a polyacrylamide gel concentration of $15 \%$. Then, the protein was transferred to a nitrocellulose membrane and the band of interest was incubated with the corresponding primary antibody for $24 \mathrm{~h}$ at $4^{\circ} \mathrm{C}$. Next, the membrane was rinsed three times with phosphate buffered saline (PBS) and incubated with secondary antibody for $1 \mathrm{~h}$ at room temperature. Finally, the ChemiDOC XRS+ imaging system (Bio-Rad, Germany) was used to develop the protein of interest through enhanced chemiluminescence reactions. The primary antibodies used were rabbit anti-goat polyclonal serum antibodies (4EBP1, Calbiochem, Germany; S6K1 and eEF2, Abcam, UK) and the secondary antibodies were goat anti-rabbit horseradish peroxidase conjugates (Beijing Synthetic Technology Co., Ltd., China).

2.4. Calculations and Statistical Analysis. Enzyme activities, mRNA expression, and 4EBP1, S6K1 and eEF2 phosphorylation were analysed using the GLM procedure for the oneway analysis of variance (ANOVA) model with SAS software. Protein expression content was calculated as the ratio of the band intensity of $\beta$-actin. Differences of $\mathrm{P}<0.05$ were considered significant and data are presented as the means \pm standard errors of the means (SEM).

\section{Results}

As shown in Table 3, high levels of Ile $(0.8 \mathrm{mM}$ and $1.6 \mathrm{mM})$ significantly increased the tissue concentration of a-amylase $(\mathrm{P}<0.001)$, the buffer release concentration $(\mathrm{P}<0.001)$, and the total concentration $(\mathrm{P}<0.001)$. The total concentrations of trypsin and chymotrypsin in each of the Ile groups were significantly higher than those in the control group $(\mathrm{P}<0.05)$, while lipase was not affected by Ile $(\mathrm{P}>0.05)$.

As shown in Figure 1, high levels of Ile $(0.8 \mathrm{mM}$ and $1.6 \mathrm{mM}$ ) significantly increased a-amylase mRNA expression $(\mathrm{P}<0.001)$, but had no effect on the mRNA expression of trypsin, chymotrypsin, or lipase $(\mathrm{P}>0.05)$.

As shown in Figure 2, Ile did not affect the level of S6K1 phosphorylation $(\mathrm{P}>0.05)$. Detection of the 4EBP1 isoforms $(\mathrm{a}, \beta$, and $\gamma)$ indicated that high levels of Ile $(0.8 \mathrm{mM}$ and $1.6 \mathrm{mM}$ ) significantly increased the expression of the $\gamma$ isoform of 4EBP1 $(\mathrm{P}<0.001)$, which means that the phosphorylation of 4EBP1 was significantly increased. The level of eEF2 phosphorylation gradually decreased with the addition of Ile and was most pronounced in the $0.8 \mathrm{mM}$ and $1.6 \mathrm{mM}$ groups $(\mathrm{P}<0.001)$.

\section{Discussion}

In this study, Ile significantly increased the total a-amylase concentration in pancreatic tissues. Compared to the control group, the total a-amylase concentrations in the $0.8 \mathrm{mM}$ and $1.6 \mathrm{mM}$ groups were increased by $346.3 \%$ and $289.4 \%$, respectively. A study on juvenile Jian carp noted that Ile significantly increased the trypsin, chymotrypsin, and aamylase activities in the hepatopancreas and intestines [12], which was similar to the results of a study in mice by Lyman and Wilcox [28]. A previous study conducted by our research team [29] also showed that short-term duodenal infusion of Ile could increase the a-amylase concentration $(\mathrm{U} / \mathrm{mg})$ and the secretion rate $(\mathrm{U} / \mathrm{h})$ by up to $84.6 \%$ and $78.6 \%$, respectively, and long-term infusion could increase the same parameters by $122.7 \%$ and $133.8 \%$, respectively. The reason why Ile has different degrees of stimulatory effects on the synthesis and secretion of a-amylase may be because 


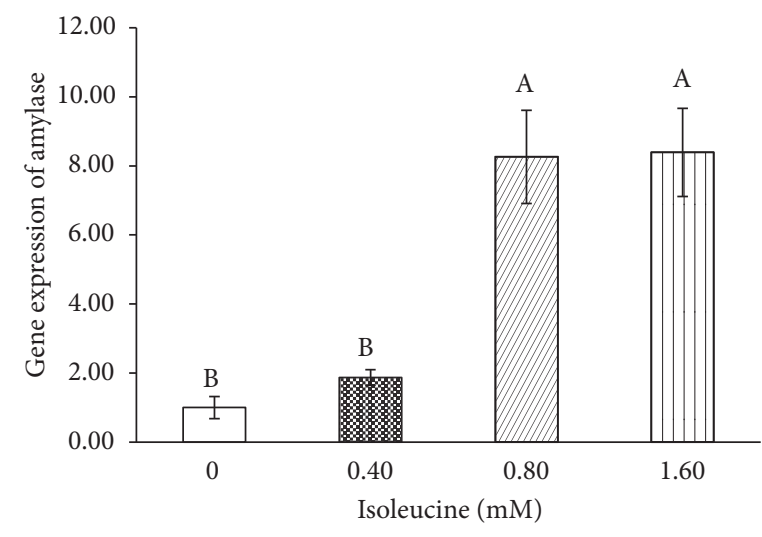

(a)

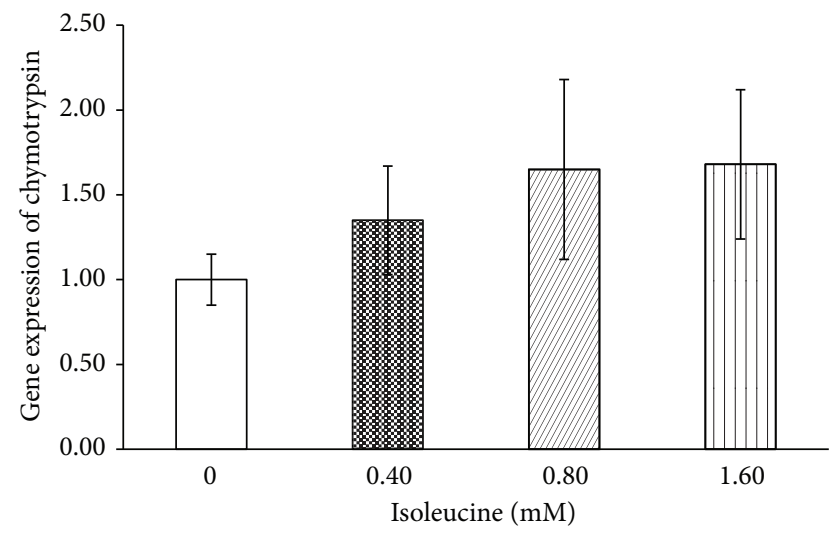

(c)

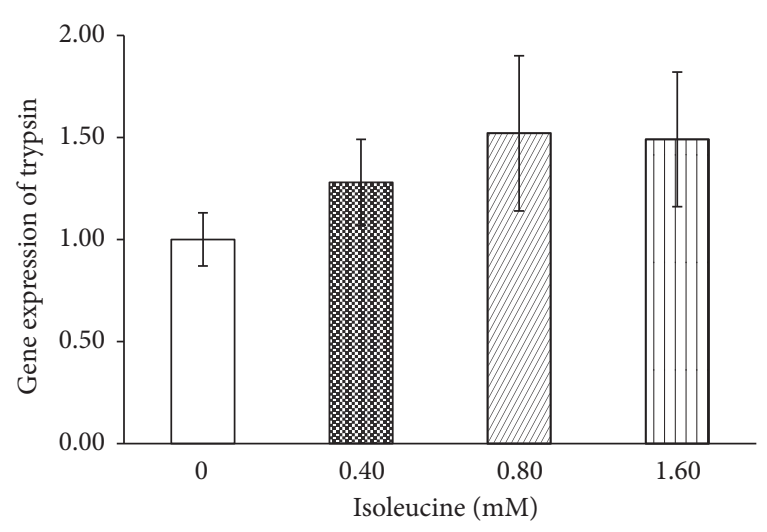

(b)

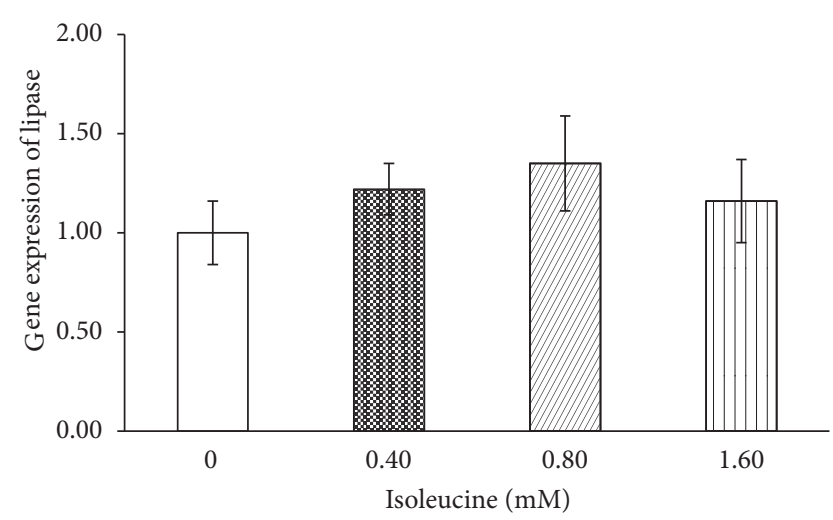

(d)

FIGURE 1: The effects of isoleucine on pancreatic amylase (a), trypsin (b), chymotrypsin (c), and lipase (d) mRNA levels in vitro. The values are the means and pooled standard errors of the means (SEM). The enzyme mRNA levels were normalized to $\beta$-actin and the values were compared to the control group, which was set to 1.00. Different letters represent significantly different values $(P<0.05, \mathrm{n}=3)$.

when nutrient infusion is performed in animals, pancreatic enzyme secretion is affected by various factors, including nutrients, hormones, nerves, and gastrointestinal motility, as well as the interactions and antagonistic effects among these factors [2]. By contrast, with in vitro incubation of pancreatic tissues, other impacting factors in in vivo studies can be ruled out and the effects of nutrients on pancreatic enzyme secretion can be studied in isolation, producing a more direct and obvious effect. Low-dose Ile has no effect on pancreatic enzyme secretion. The reason for this remains to be further investigated as few studies regarding the effects of Ile on pancreatic exocrine functions in ruminants exist and no current studies regarding the effects of Ile on enzyme secretion in in vitro pancreatic tissues or acinar cells in ruminants are known. The effects of Ile on pancreatic enzyme mRNA expression may, to a certain extent, explain that lowdose Ile had no effect on a-amylase secretion in the pancreas. High levels of Ile $(0.8 \mathrm{mM}$ and $1.6 \mathrm{mM})$ promoted a-amylase mRNA expression and the effect was extremely significant.

Amino acids not only serve as substrates for protein synthesis but also regulate protein synthesis by modulating translation initiation and translation rates [30]. Previous studies have shown that Ile can increase mTOR phosphorylation and the synthesis rate of casein fragments in mammary gland tissues $[19,20]$. Arriola Apelo et al. also showed that Ile can stimulate the mTOR signalling pathway in mammary gland tissues [31]. In this study, Ile significantly increased the level of 4EBP1 phosphorylation. 4EBP1 acts as a downstream signalling factor of mTOR and is directly regulated by mTOR [14]. Once being phosphorylated by mTOR, 4EBP1 releases eukaryotic initiation factor 4E (eIF4E) from the inactive eIF4E-4EBP1 complex to form the active eIF4G-eIF4E complex that binds to mRNA and initiates translation [32]. Therefore, Ile can regulate protein synthesis by modulating the mTOR signalling pathway. However, since Ile does not affect the level of S6K1 phosphorylation, the results of this study indicate that the regulation of protein synthesis by Ile does not depend on the mTOR-S6K1 pathway.

eEF2 plays a crucial role during the elongation stage of protein synthesis, in which the ribosome moves by the equivalent of one codon relative to the mRNA, and the peptidyl-tRNA migrates from the ribosomal A site into the $\mathrm{P}$ site, following formation of the new peptide bond [16], while phosphorylated eEF2 is inactive during protein translation [18]. Studies have shown that amino acid deficiency increases the degree of eEF2 phosphorylation [33]. By studying the effects of different amino acids on the protein synthesis pathway in mammary gland tissues, Arriola Apelo et al. 


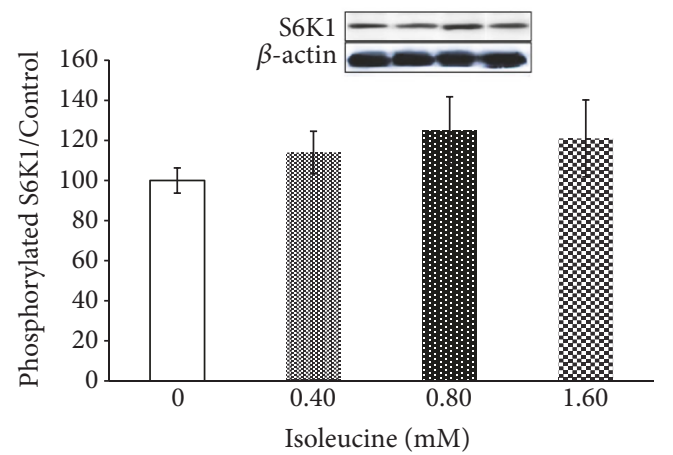

(a)

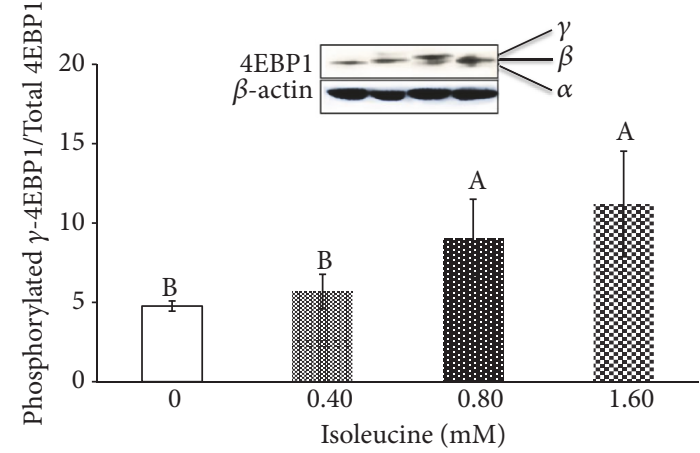

(b)

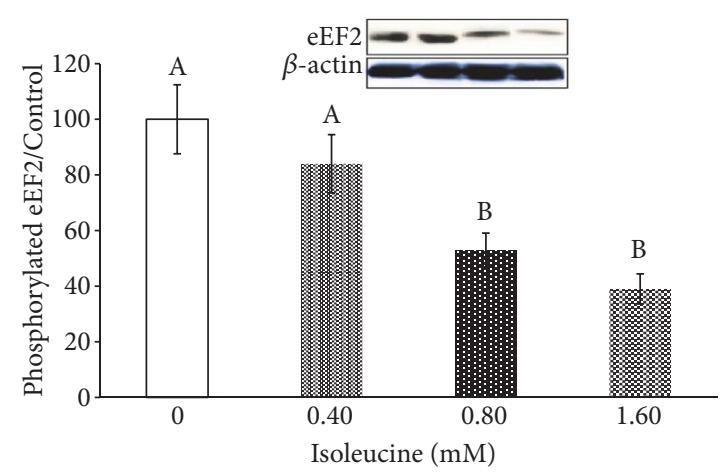

(c)

FIgURE 2: The effects of isoleucine on the ratio of phosphorylated to total mTOR signalling pathway factors in pancreas tissue. Panel (a) represents S6K1; Panel (b) represents 4EBP1 (a, $\beta$, and $\gamma$-forms are denoted); Panel (c) represents eEF2. The data are the means and pooled standard errors of the means (SEM). Different letters represent significantly different values $(P<0.05, \mathrm{n}=3)$.

[31] showed that Ile can linearly reduce the level of eEF2 phosphorylation and thus increase its activity. A study by Proud et al. showed that eEF2 can be regulated by mTOR [34]. In this study, as the level of Ile increased, the degree of eEF2 phosphorylation gradually decreased, with a particularly significant effect under high-doses of Ile, which was consistent with the above findings.

\section{Conclusions}

High doses of Ile can regulate the excretion of enzymes, especially a-amylase, in dairy goat pancreatic tissue by modulating mTOR signalling and this regulation is independent of the mTOR-S6K1 pathway.

\section{Data Availability}

The data used to support the findings of this study are available from the corresponding author upon request.

\section{Conflicts of Interest}

The authors declare that they have no conflicts of interest.

\section{Acknowledgments}

This work was supported by the National Key Research and Development Program of China (nos. 2018YFD0501600 and 2017YFD0500500) and the National Natural Science Foundation of China (nos. 31672451 and 31472122).

\section{References}

[1] G. B. Huntington, "Starch utilization by ruminants: from basics to the bunk," Journal of Animal Science, vol. 75, no. 3, pp. 852867, 1997.

[2] D. L. Harmon, R. M. Yamka, and N. A. Elam, "Factors affecting intestinal starch digestion in ruminants: A review," Canadian Journal of Animal Science, vol. 84, no. 3, pp. 309-318, 2004.

[3] D. L. Harmon, "Understanding starch utilization in the small intestine of cattle," Asian-Australasian Journal of Animal Sciences, vol. 22, no. 7, pp. 915-922, 2009.

[4] G. Wu, "Functional amino acids in nutrition and health," Amino Acids, vol. 45, no. 3, pp. 407-411, 2013.

[5] G. Wu, F. W. Bazer, Z. Dai, D. Li, J. Wang, and Z. Wu, "Amino acid nutrition in animals: Protein synthesis and beyond," Annual Review of Animal Biosciences, vol. 2, pp. 387-417, 2014.

[6] J. T. Brosnan and M. E. Brosnan, "Branched-chain amino acids: enzyme and substrate regulation," Journal of Nutrition, vol. 136, no. 1, pp. 207S-211S, 2006.

[7] K. S. Nair and K. R. Short, "Hormonal and signaling role of branched-chain amino acids," Journal of Nutrition, vol. 135, no. 6, pp. 1547S-1552S, 2005.

[8] B. T. Richert, R. D. Goodband, M. D. Tokach, and J. L. Nelssen, "Increasing valine, isoleucine, and total branched-chain amino 
acids for lactating sows," Journal of Animal Science, vol. 75, no. 8, pp. 2117-2128, 1997.

[9] Z. P. Yu, M. Xu, K. Liu, J. H. Yao, H. X. Yu, and F. Wang, "Leucine markedly regulates pancreatic exocrine secretion in goats," Journal of Animal Physiology and Animal Nutrition, vol. 98, no. 1, pp. 169-177, 2014.

[10] Z. P. Yu, M. Xu, F. Wang et al., "Effect of duodenal infusion of leucine and phenylalanine on intestinal enzyme activities and starch digestibility in goats," Livestock Science, vol. 162, no. 1, pp. 134-140, 2014.

[11] K. Liu, Y. Liu, S. M. Liu et al., "Relationships between leucine and the pancreatic exocrine function for improving starch digestibility in ruminants," Journal of Dairy Science, vol. 98, no. 4, pp. 2576-2582, 2015.

[12] J. Zhao, Y. Liu, J. Jiang et al., "Effects of dietary isoleucine on growth, the digestion and absorption capacity and gene expression in hepatopancreas and intestine of juvenile Jian carp (Cyprinus carpio var. Jian)," Aquaculture, vol. 368-369, pp. 127128, 2012.

[13] S. S. Schalm and J. Blenis, "Identification of a conserved motif required for mTOR signaling," Current Biology, vol. 12, no. 8, pp. 632-639, 2002.

[14] S. S. Schalm, D. C. Fingar, D. M. Sabatini, and J. Blenis, "TOS motif-mediated raptor binding regulates $4 \mathrm{E}-\mathrm{BP} 1$ multisite phosphorylation and function," Current Biology, vol. 13, no. 10, pp. 797-806, 2003.

[15] S. A. Burgos, M. Dai, and J. P. Cant, "Nutrient availability and lactogenic hormones regulate mammary protein synthesis through the mammalian target of rapamycin signaling pathway," Journal of Dairy Science, vol. 93, no. 1, pp. 153-161, 2010.

[16] D. C. Fingar, C. J. Richardson, A. R. Tee, L. Cheatham, C. Tsou, and J. Blenis, "mTOR controls cell cycle progression through its cell growth effectors $\mathrm{S} 6 \mathrm{~K} 1$ and $4 \mathrm{E}-\mathrm{BP} 1$ /eukaryotic translation initiation factor 4E," Molecular and Cellular Biology, vol. 24, no. 1, pp. 200-216, 2004.

[17] X. Wang and C. G. Proud, "The mTOR pathway in the control of protein synthesis," Physiology Journal, vol. 21, no. 5, pp. 362-369, 2006.

[18] X. Wang, W. Li, M. Williams, N. Terada, D. R. Alessi, and C. G. Proud, "Regulation of elongation factor 2 kinase by $\mathrm{p} 90^{R S K 1}$ and p70 S6 kinase," EMBO Journal, vol. 20, no. 16, pp. 4370-4379, 2001.

[19] J. A. Appuhamy, A. L. Bell, W. A. Nayananjalie, J. Escobar, and M. D. Hanigan, "Essential amino acids regulate both initiation and elongation of mRNA translation independent of insulin in MAC-T cells and bovine mammary tissue slices," Journal of Nutrition, vol. 141, no. 6, pp. 1209-1215, 2011.

[20] J. A. Appuhamy, N. A. Knoebel, W. A. Nayananjalie, J. Escobar, and M. D. Hanigan, "Isoleucine and leucine independently regulate mtor signaling and protein synthesis in MAC-T cells and bovine mammary tissue slices," Journal of Nutrition, vol. 142, no. 3, pp. 484-491, 2012.

[21] W. W. Umbreit, R. H. Burris, and J. F. Stauffer, Manometric Techniques, vol. 10, 1964.

[22] AOAC, Official Methods of Analysis, Association of Analytical Chemists, Washington, DC, USA, 16th edition, 1999.

[23] P. J. van Soest, J. B. Robertson, and B. A. Lewis, "Methods for dietary fiber, neutral detergent fiber, and nonstarch polysaccharides in relation to animal nutrition," Journal of Dairy Science, vol. 74, no. 10, pp. 3583-3597, 1991.
[24] D. C. Wathes, Z. Cheng, W. Chowdhury et al., "Negative energy balance alters global gene expression and immune responses in the uterus of postpartum dairy cows," Physiological Genomics, vol. 39, no. 1, pp. 1-13, 2009.

[25] K. J. Livak and T. D. Schmittgen, "Analysis of relative gene expression data using real-time quantitative PCR and the $2^{-\Delta \Delta C_{T}}$ method," Methods, vol. 25, no. 4, pp. 402-408, 2001.

[26] I. M. Frota, C. C. Leitao, J. J. Costa et al., "Effects of BMP-7 and FSH on the development of goat preantral follicles and levels of mRNA for FSH-R, BMP-7 and BMP receptors after in-vitro culture," Animal Reproduction, vol. 8, no. 1-2, pp. 25-31, 2011.

[27] S. J. Crozier, M. D. Sans, C. H. Lang, L. G. D’Alecy, S. A. Ernst, and J. A. Williams, "CCK-induced pancreatic growth is not limited by mitogenic capacity in mice," American Journal of Physiology-Gastrointestinal and Liver Physiology, vol. 294, no. 5, pp. G1148-G1157, 2008.

[28] R. L. Lyman and S. S. Wilcox, "Effect of acute amino acid deficiencies on carcass composition and pancreatic function in the force-fed rat," Journal of Nutrition, vol. 79, no. 1, pp. 28-36, 1963.

[29] K. Liu, J. Shen, Y. Cao, C. Cai, and J. Yao, "Duodenal infusions of isoleucine influence pancreatic exocrine function in dairy heifers," Archives of Animal Nutrition, vol. 72, no. 1, pp. 31-41, 2018.

[30] S. R. Kimball and L. S. Jefferson, "Control of protein synthesis by amino acid availability," Current Opinion in Clinical Nutrition \& Metabolic Care, vol. 5, no. 1, pp. 63-67, 2002.

[31] S. I. Arriola Apelo, L. M. Singer, X. Y. Lin, M. L. McGilliard, N. R. St-Pierre, and M. D. Hanigan, "Isoleucine, leucine, methionine, and threonine effects on mammalian target of rapamycin signaling in mammary tissue," Journal of Dairy Science, vol. 97, no. 2, pp. 1047-1056, 2014.

[32] S. R. Kimball and L. S. Jefferson, "Regulation of global and specific mRNA translation by oral administration of branchedchain amino acids," Biochemical and Biophysical Research Communications, vol. 313, no. 2, pp. 423-427, 2004.

[33] X. Wang, L. E. Campbell, C. M. Miller, and C. G. Proud, “Amino acid availability regulates p70 $\mathrm{S} 6$ kinase and multiple translation factors," Biochemical Journal, vol. 334, no. 1, pp. 261-267, 1998.

[34] C. G. Proud, "Amino acids and mTOR signalling in anabolic function," Biochemical Society Transactions, vol. 35, no. 5, pp. 1187-1190, 2007. 


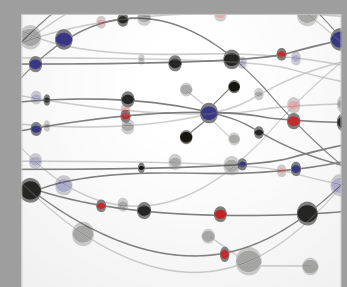

The Scientific World Journal
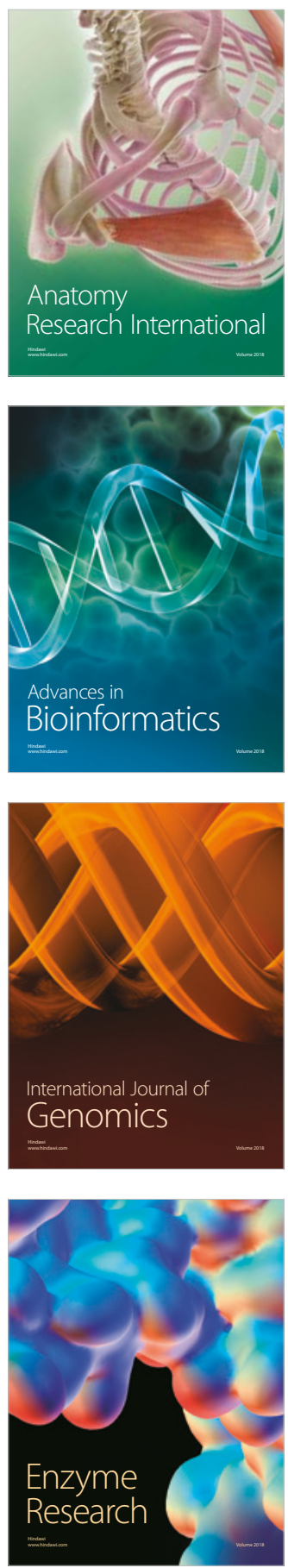
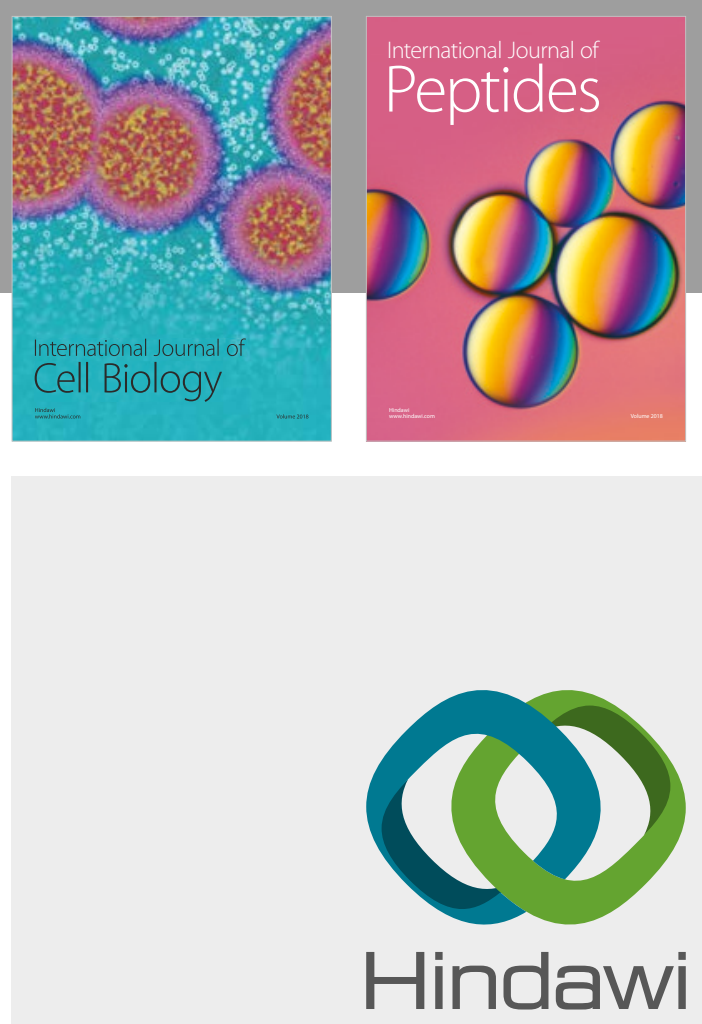

Submit your manuscripts at

www.hindawi.com
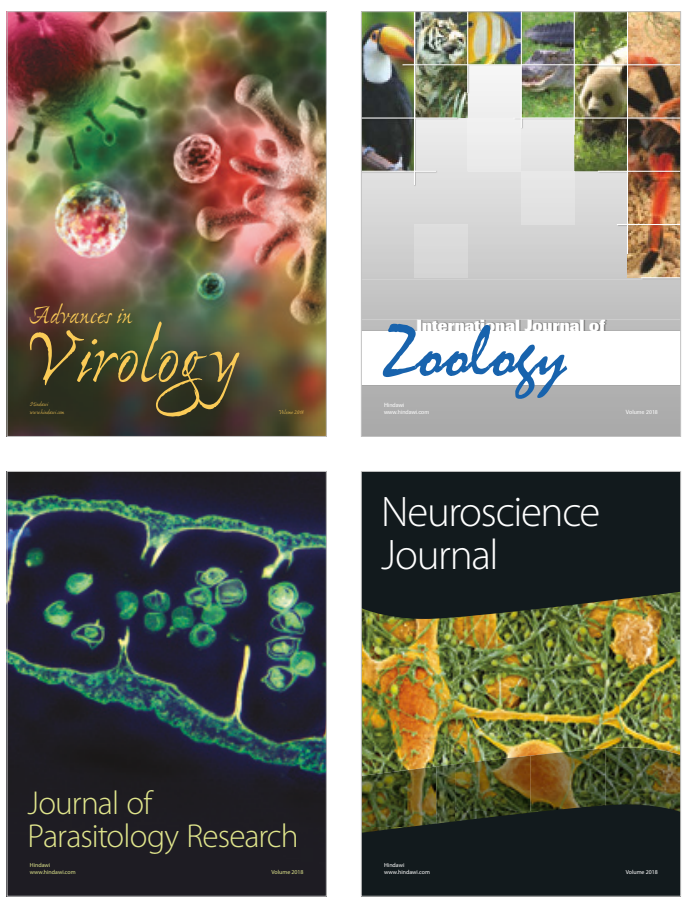
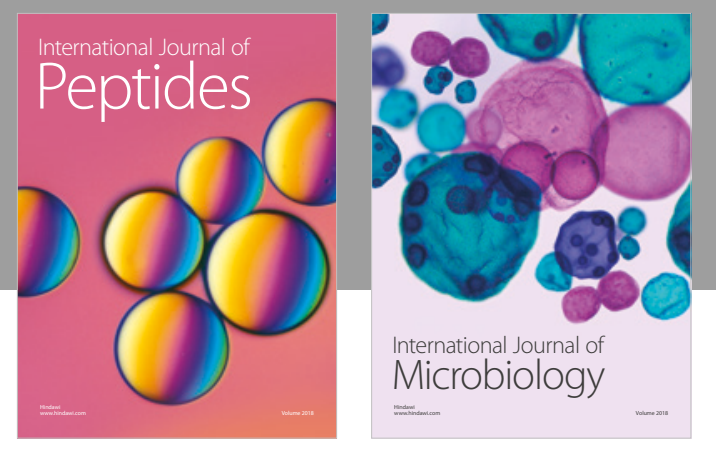

nternational Journal of Microbiology
Journal of
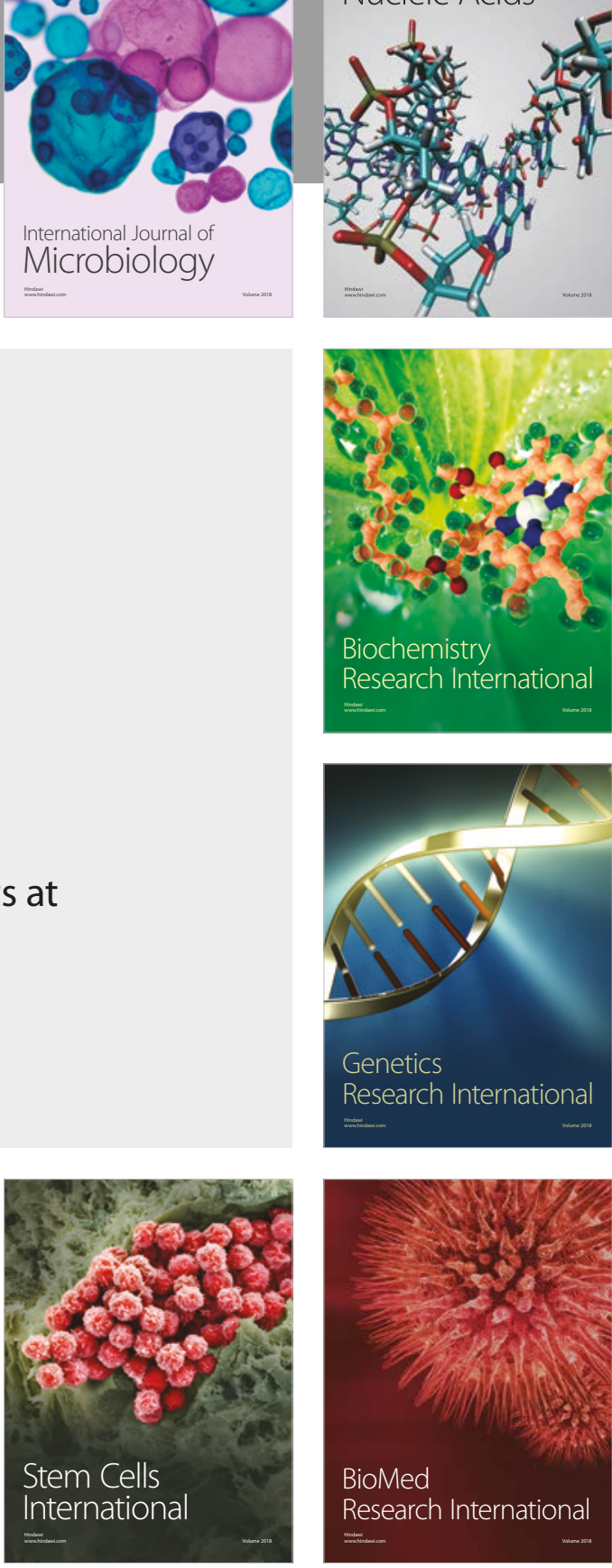
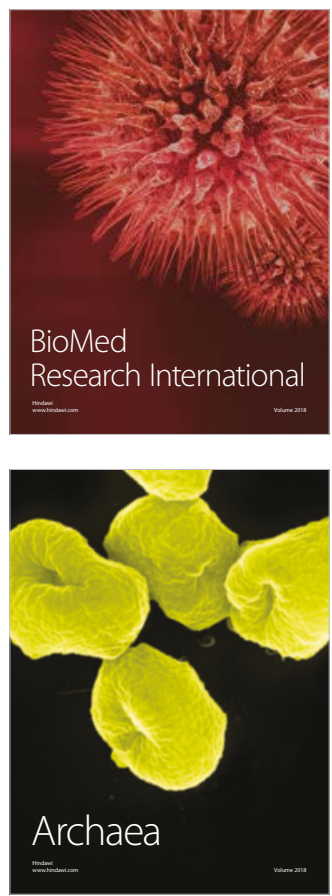